\title{
EFFECT OF HEATING TEMPERATURE AND MODIFICATION OF Al - 27\% Cu - 6\% Si MELT ON THE STRUCTURE AND PHASE COMPOSITION OF CRYSTALLIZED SPECIMENS
}

\author{
K. V. Nikitin, ${ }^{1}$ O. A. Chikova, ${ }^{2}$ I. Yu. Timoshkin, ${ }^{1}$ and A. N. Konstantinov ${ }^{3}$
}

Translated from Metallovedenie i Termicheskaya Obrabotka Metallov, No. 4, pp. 30 - 35, April, 2013.

\begin{abstract}
The effect of liquid-phase treatment of $\mathrm{Al}-27 \mathrm{wt} . \% \mathrm{Cu}-6 \mathrm{wt} . \% \mathrm{Si}$ melt used for making A34 solder on the structure and phase composition of crystallized specimens is studied. Pioneer data are obtained on the changes in the microstructure of the alloy due to its direct heating on the specimen stage of an NTEGRA Therma scanning probe microscope at 150 and $300^{\circ} \mathrm{C}$.
\end{abstract}

Key words: solder, microstructure, melt, differential thermal analysis, electron microscopy, scanning probe microscopy.

\section{INTRODUCTION}

Alloy $\mathrm{Al}-27 \% \mathrm{Cu}-6 \% \mathrm{Si}^{4}$ has a composition close to an eutectic one $[1,2]$ and is widely used as a solder (A34) for soldering aluminum and its alloys [3]. The main problem in fabrication of cast solder A34 is the formation of a ternary $\left(\alpha+\mathrm{CuAl}_{2}+\mathrm{Si}\right)$ eutectic and primary silicon crystals in its structure, which lowers substantially the process and operating properties of the alloys.

It is known $[4,5]$ that superheating of melts of the $\mathrm{Al}$ - Si system to a temperature $T^{*}$ specific for each composition transfers the alloy irreversibly into a more homogeneous state (i.e., homogenizes the metal), which causes substantial changes in the structure and phase composition of the solid alloy in subsequent cooling and crystallization even at a moderate rate (on the order of $1-10 \mathrm{~K} / \mathrm{sec}$ ). According to $[4,5]$, the temperature $T^{*}$ (the temperature of homogenization of liquid metal) corresponds to the start of the coinciding high-temperature region of the heating and cooling polytherms for some structurally sensitive property of the melt (for example, the viscosity). In an earlier study [6] we analyzed temperature dependences of the kinematic viscosity of

1 Samara State Technical University, Samara, Russia (e-mail: himcity@mail.ru).

2 Ural State Federal University in the Name of the First President of Russia B. N. Eltsyn, Ekaterinburg, Russia.

3 Ural State Pedagogical University, Institute for Physics and Technology, Ekaterinburg, Russia.

4 Here and below in the paper the content of elements in the alloy is given in mass percent. a melt obtained in heating and subsequent cooling of a specimen and determined the temperature regime of homogenization of the melt considered, i.e., $T^{*}=950-1000^{\circ} \mathrm{C}$. In the present work heating of a melt to a temperature above $T^{*}=950^{\circ} \mathrm{C}$ is treated as an independent method of modifying of the microstructure of a cast metal.

The aim of the present work was to study the effect of the temperature of heating and modifying of a melt of $\mathrm{Al}-$ $27 \% \mathrm{Cu}-6 \% \mathrm{Si}$ on the structure and phase composition of crystallized specimens with the aim to optimize the process of fabrication of ingots of solder A34.

\section{METHODS OF STUDY}

We melted specimens of alloy $\mathrm{Al}-27 \% \mathrm{Cu}-6 \% \mathrm{Si}$ in the Center for Casting Technologies of the Samara State Technical University by various modes of temperature treatment of the melt (Table 1). The blend consisted of electrotechnical waste of A5 aluminum and copper plus crystalline silicon of grade $\mathrm{Kr} 0$. The blend contained about $95 \%$ deformed waste (aluminum and copper: a D-blend). Then the melt was subjected to a temperature-time treatment (TTT), i.e., superheating at $T_{\mathrm{s}}=1000^{\circ} \mathrm{C}$. The temperature of superheating of the melt was determined earlier [6] from the results of a study of the kinematic viscosity of metallic liquid. The melt was held at $T_{\mathrm{s}}$ for $10 \mathrm{~min}$ and then cooled in the crucible in air to the casting temperature $T_{\mathrm{c}}=600^{\circ} \mathrm{Ct}$ a rate of about $10 \mathrm{~K} / \mathrm{sec}$. To perform fine-crystal remelting (FCR) a part of the melt was not subjected to TTT but was rather cast into a roller mold to obtain a ribbon with a thickness of 
TABLE 1. Processes of Production and Parameters of Microstructure of Alloy $\mathrm{Al}-27 \% \mathrm{Cu}-6 \% \mathrm{Si}$

\begin{tabular}{lccccc}
\hline \multicolumn{1}{c}{ Process of solder production } & & $d_{\text {den }}, \mu \mathrm{m}$ & $H V_{\text {eut }}, \mathrm{MPa}$ & $d_{\mathrm{Si}}, \mu \mathrm{m}$ & $\mathrm{Si}$, vol.\% \\
\hline$T_{\mathrm{s}}=T_{\mathrm{c}}=600^{\circ} \mathrm{C}$ & $(1)$ & 327 & 2158 & 20 & 5.5 \\
$T_{\mathrm{s}}=1000^{\circ} \mathrm{C}, T_{\mathrm{c}}=600^{\circ} \mathrm{C}$ & $(2)$ & 200 & 2020 & 17 & 4.3 \\
$T_{\mathrm{s}}=1000^{\circ} \mathrm{C}, T_{\mathrm{c}}=600^{\circ} \mathrm{C}, 5$ wt.\% FCR & $(3)$ & 300 & 2530 & 14 & 6.9 \\
$T_{\mathrm{s}}=T_{\mathrm{c}}=600^{\circ} \mathrm{C}, 5$ wt.\% FCR & $(4)$ & 310 & 2059 & 17 & 5.8 \\
\hline
\end{tabular}

Note. The variants of production of the alloy are numbered conventionally in parentheses.

Notations: $T_{\mathrm{S}}$ is the temperature of superheating of the alloy; $T_{\mathrm{c}}$ is the casting temperature; FCR is used for fine crystal remelting; $d_{\mathrm{den}}$ is the size of the dendrites of $\alpha-\mathrm{Al} ; H V_{\text {eut }}$ is the microhardness of the eutectic; $d_{\mathrm{Si}}$ is the size of the Si crystals.

up to $2 \mathrm{~mm}$. In this case the cooling rate was about $10^{3} \mathrm{~K} / \mathrm{sec}$. The ribbon obtained by the method of FCR was introduced as a modifying additive into the melt at the casting temperature $2 \mathrm{~min}$ before casting. The melts treated by variants $1-4$ (Table 1 ) were teemed into a chill mold to obtain bars with a diameter of $4 \mathrm{~mm}$ and a length of $150 \mathrm{~mm}$.

The metallographic study of alloy $\mathrm{Al}-27 \% \mathrm{Cu}-6 \% \mathrm{Si}$ was performed with the help of a "Neophot-32" light microscope, an MBS-9 binocular microscope, an NTEGRA Therma scanning probe microscope equipped with a hot bench, and a Zeiss AURIGA CrossBeam scanning electron microscope with a function of microscopic $\mathrm{x}$-ray spectrum analysis (MXRSA). The microhardness of individual structural components was measured with the help of a PMT-3 device at a load of 2 and $5 \mathrm{~N}$. The metallographic characteristics, i.e., the volume fractions of the phases, the mean grain size, the mean size of the individual components (primary crystals) and their microhardness, were determined by the standard methods.

Differential thermal analysis of alloy $\mathrm{Al}-27 \% \mathrm{Cu}-$ $6 \% \mathrm{Si}$ was performed with the help of a BDTA-8M3 high-temperature differential thermal analyzer, which allowed us to determine the temperatures of the phase transformations in the range from room temperature to $2000^{\circ} \mathrm{C}$ at various rates of cooling and heating $(2.5 \mathrm{~K} / \mathrm{min}, 5,10,20$, $40,80 \mathrm{~K} / \mathrm{min}$ ) [7, 8]. The mass of the specimens chosen for the DTA was about $1 \mathrm{~g}$. We used beryllium crucibles $(\mathrm{BeO})$ of cylindrical shape with an internal diameter of $7 \mathrm{~mm}$ and a height of $13 \mathrm{~mm}$. The working chamber was evacuated preliminarily to $0.001 \mathrm{~Pa}$. Then we fed helium to a pressure of about $10^{5} \mathrm{~Pa}$. The DTA was performed in heating of the melt and subsequent cooling at a rate of 10,20 , and $40 \mathrm{~K} / \mathrm{min}$. Two series of tests were performed with different standards, i.e., a zone-cleaned single crystal of tungsten and aluminum of grade A999. In the former case the specimens were heated to $1100^{\circ} \mathrm{C}$, held for $10 \mathrm{~min}$ and then cooled; in the latter case the specimens were heated to $610^{\circ} \mathrm{C}$ and cooled. The temperatures of the phase transformations were determined as points of intersection of the zero line of the thermogram $(\Delta T=0)$ with continuations of the rectilinear parts of the endo- and exothermic peaks. The accuracy of the determination of the values of the critical points was $\pm 3^{\circ} \mathrm{C}$.

\section{RESULTS AND DISCUSSION}

The results of the DTA of alloy $\mathrm{Al}-27 \% \mathrm{Cu}-6 \% \mathrm{Si}$ obtained by two variants of remelting are presented in Tables 2 and 3 and Figs. 1 and 2.

TABLE 2. Results of Differential Thermal Analysis of Alloy Al $27 \% \mathrm{Cu}-6 \% \mathrm{Si}$

\begin{tabular}{lccccccc}
\hline Standard & VFA & $v, \mathrm{~K} / \mathrm{min}$ & $T_{S},{ }^{\circ} \mathrm{C}$ & $T_{L},{ }^{\circ} \mathrm{C}$ & $S, \mathrm{~mm}^{2}$ & $l, \mathrm{~mm}$ & $h, \mathrm{~mm}$ \\
\hline $\mathrm{A} 999$ & 1 & 10 & $\frac{499}{484}$ & $\frac{516}{504}$ & $\frac{57}{53}$ & $\frac{6}{7}$ & $\frac{26}{26}$ \\
& & 20 & $\frac{501}{479}$ & $\frac{521}{501}$ & $\frac{126}{106}$ & $\frac{8.5}{9.0}$ & $\frac{34}{35}$ \\
& & 40 & $\frac{504}{470}$ & $\frac{533}{499}$ & $\frac{216}{201}$ & $\frac{17}{13}$ & $\frac{51}{47}$ \\
& 2 & 10 & $\frac{504}{487}$ & $\frac{521}{510}$ & $\frac{51}{40}$ & $\frac{6}{7}$ & $\frac{26}{27}$ \\
& & 20 & $\frac{504}{482}$ & $\frac{527}{507}$ & $\frac{106}{90}$ & $\frac{8}{8}$ & $\frac{33.5}{36.0}$ \\
& & 40 & $\frac{507}{470}$ & $\frac{539}{504}$ & $\frac{233}{214}$ & $\frac{12}{12}$ & $\frac{47}{47}$ \\
& 1 & 40 & $\frac{504}{468}$ & $\frac{541}{499}$ & $\frac{227}{160}$ & $\frac{13}{14}$ & $\frac{43.0}{50.5}$ \\
& 2 & 40 & $\frac{510}{470}$ & $\frac{544}{504}$ & $\frac{248}{221}$ & $\frac{13}{17}$ & $\frac{50}{52}$ \\
\hline
\end{tabular}

Notations: VFA is used for the variant of fabrication of the alloy (in accordance with Table 1$) ; T_{S}$ is the solidus temperature; $T_{L}$ is the liquidus temperature; $S$ is the area of the peak; $l$ is the width of the peak; $h$ is the height of the peak; the numerators present the characteristics obtained in heating; the denominators present the characteristics obtained in cooling at rate $v$.

TABLE 3. Results of Differential Thermal Analysis of Alloy Al $25 \% \mathrm{Cu}-6 \% \mathrm{Si}$

\begin{tabular}{lccc}
\hline Process of fabrication & $\Delta H_{\text {melt }}, \mathrm{J} / \mathrm{kg}$ & $\Delta H_{\mathrm{cr}}, \mathrm{J} / \mathrm{kg}$ & $E_{\mathrm{cr}}, \mathrm{kJ} / \mathrm{mole}$ \\
\hline$T_{\mathrm{s}}=T_{\mathrm{c}}=600^{\circ} \mathrm{C}($ variant 1$)$ & 990 & 833 & 520 \\
$T_{\mathrm{s}}=1000^{\circ} \mathrm{C}, T_{\mathrm{c}}=600^{\circ} \mathrm{C}$ & & & \\
$\quad($ variant 2) & 833 & 707 & 415 \\
\hline
\end{tabular}



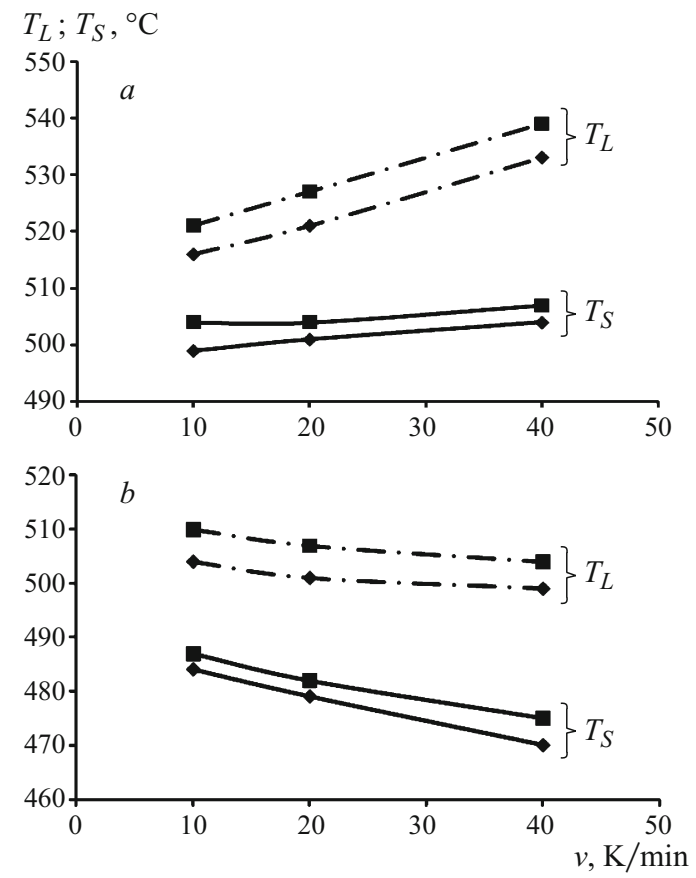

Fig. 1. Dependences of the temperatures of liquidus $T_{L}$ and solidus $T_{S}$ of alloy $\mathrm{Al}-27 \% \mathrm{Cu}-6 \% \mathrm{Si}$ fabricated by variants $l(\diamond)$ and $2(\boldsymbol{\square})$ on the rates of heating $(a)$ and cooling $(b)$. The standard is A999.

It can be seen from Fig. 1 that the liquidus and solidus temperatures for the alloy obtained by variant 2 (with TTT) are $3-5^{\circ} \mathrm{C}$ higher than those for the alloy melted without TTT (variant 1 ) The growth in the liquidus and solidus temperatures also increases the crystallization range of the alloy produced by variant 2 (Fig. 2).

According to different studies [9-11], the area of a peak on a DTA curve is proportional to the heat of the chemical reaction or physical transformation. This approach is used for determining the heat of reaction $\Delta H$ from the area of the peak on the TDA curve, i.e.,

$$
\Delta H_{\mathrm{m}}=k A,
$$

where $A$ is the area of the peak on the DTA curve and $k$ is the calibrating coefficient (depends on the shape and on the thermal conductivity of the specimen and is determined by the calibration of the system with the help of compounds for which the heat of the reaction is known). To determine the calibration coefficient we performed an experiment with aluminum of grade A999. It has been shown that $k=7.86 \mathrm{~J} /$ conv. units for $v=20 \mathrm{~K} / \mathrm{min}$. It is known from [9-11] that if we plot a dependence in coordinates $\ln b / T_{\mathrm{m}}^{2}-1 / T_{\mathrm{m}}$, its slope is equal to the activation energy

$$
\mathrm{d} \ln \left(b / t_{\mathrm{m}}^{2}\right) / \mathrm{d}\left(1 / t_{\mathrm{m}}\right)=-E / R,
$$

where $b$ is the heating rate and $t_{\mathrm{m}}$ is the temperature corresponding to the maximum value of $\Delta t$ on the thermogram.

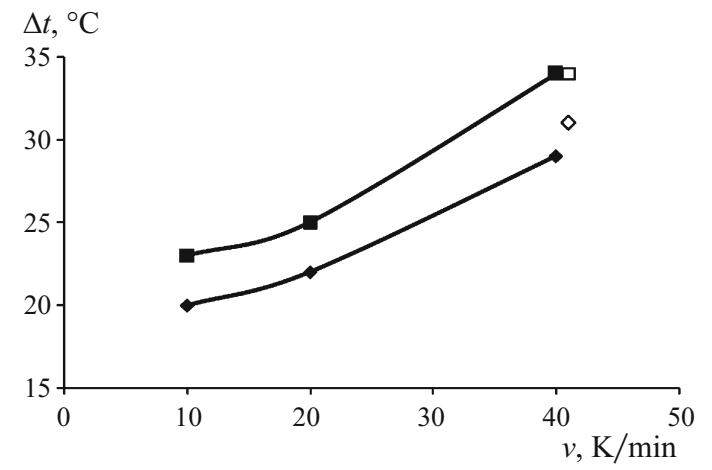

Fig. 2. Dependence of the range of crystallization $\Delta t$ of specimens of alloy $\mathrm{Al}-27 \% \mathrm{Cu}-6 \% \mathrm{Si}$ on the cooling rate. The standards are a zone-cleaned tungsten single crystal (the empty marks) and aluminum of grade A999 (the filled marks): $\diamond, \diamond$ and $\mathbf{\square}, \square$ ) melt by variants 1 and 2 respectively.

The results of the computation of the specific heats of melting $\Delta H_{\text {melt }}$ and crystallization $\Delta H_{\mathrm{cr}}$, and of the activation energy $E_{\mathrm{cr}}$ for the process of crystallization of alloy $\mathrm{Al}-$ $27 \% \mathrm{Cu}-6 \% \mathrm{Si}$ are presented in Table 3. Thus, the data of the DTA of the alloy obtained by the traditional (variant 1 ) and experimental (variant 2 ) processes show that heating of the melt to $1000^{\circ} \mathrm{C}$ causes stage decrease in the heat of phase transformations and in the activation energy of the diffusion processes.

The microstructure of the alloys obtained by different variants is presented in Fig. 3. It can be seen that the structure of all the specimens is eutectic [1,2]. We observe primary crystals of $\mathrm{Si}$, dendrites of $\alpha-\mathrm{Al}$ and $\mathrm{CuAl}_{2}$, and a multiphase eutectic $\left(\mathrm{Al}+\mathrm{Si}+\mathrm{CuAl}_{2}\right)$. The primary crystals of $\mathrm{Si}$ in the specimen obtained by variant 1 have well-cut faces. The temperature and time treatment of the melt (variant 2 ) promotes formation of primary crystals of $\mathrm{Si}$ with dendritic morphology.

$\mathrm{CuAl}_{2}$ intermetallics grow primarily in the form of dendrite arms with round cross section. The $\mathrm{CuAl}_{2}$ phase is characterized by higher geometric perfection, i.e., constant angles between the arms of adjacent orders. We also observe anisotropy of growth of the $\mathrm{CuAl}_{2}$ intermetallics, which manifests itself primarily in the development of the first-order arms.

The ternary $\mathrm{Al}+\mathrm{Si}+\mathrm{CuAl}_{2}$ eutectic has a cellular structure. Dark layers containing Si crystals are arranged over the boundaries of cells. It seems that the melt has undergone segregation with respect to silicon, which has crystallized in the last turn, and the formed segregation zones mark subgrain boundaries. Such an eutectic can be classified as a "rose" type with granular segregations over cell boundaries. Homogenizing superheating of liquid metal (variant 2) followed by cooling and crystallization affects the volume fraction and the morphology of the segregations of the primary crystals of $\mathrm{Si}, \mathrm{CuAl}_{2}$ and the eutectic. The morphology of the silicon crystals changes too; the form of their growth 
Fig. 3. Microstructure of alloy $\mathrm{Al}-$ $27 \% \mathrm{Cu}-6 \% \mathrm{Si}$ obtained by variants $1(a), 2(b), 3(a)$, and $4(b)$ (Table 1). Light microscope.
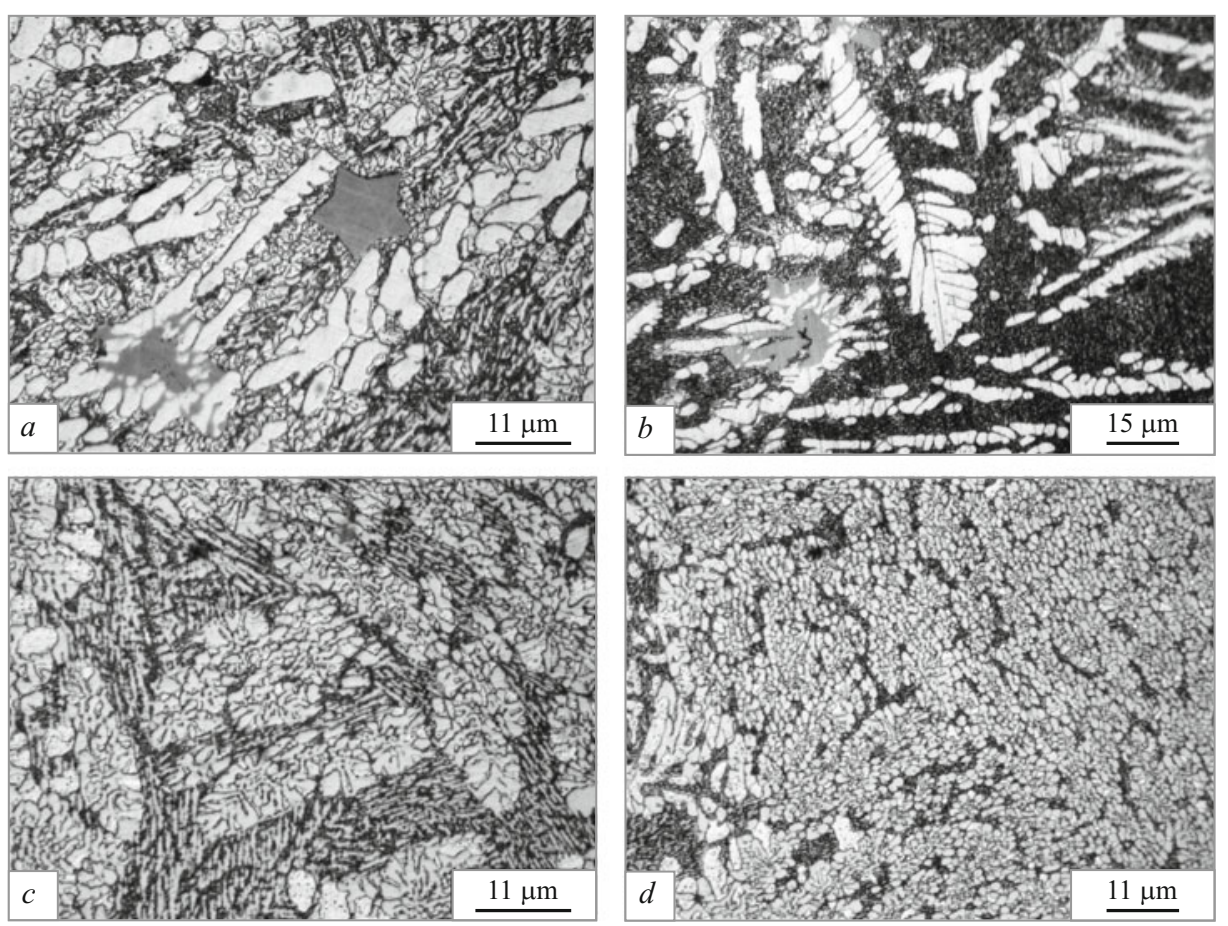

changes from a facial one to a dendritic one, and their content decreases. The $\mathrm{CuAl}_{2}$ intermetallics preserve a dendritic form of growth but the branching of the secondary arms lowers, the thickness of the primary arms decreases and so does the total number of the crystals. The morphology of the eutectic changes from a cellular one to a globular one, and layers with silicon crystals over sub-boundaries of the ternary eutectic disappear partially.

The differences in the microstructure of the specimens obtained after the two variants of treatment of melt agree well with the results of our analysis of $3 d$-images of microstructures (see Fig. 4). According to the data of the microscopic x-ray spectrum analysis of specimens fabricated by variant 2 , their aluminum-base $\alpha$-solid solution is supersatu- rated with copper (to $9-10$ at.\%) and silicon (to $7-10$ at.\%) (Fig. 5) as compared to the alloy fabricated by variant 1 .

Thus, the results of the comparative metallographic analysis show that the TTT of the melt (variant 2 ) lowers its microscopic heterogeneity due to refinement of the structural components of the melt inherited from the initial blend materials. A low additive of fine-crystalline remelted metal of a similar composition into a heat-treated melt (variant 3 ) creates a suspension of fine clustered and colloidal particles in the latter, which play the role of ready nuclei for crystallization.

We used scanning probe microscopy to study the effect of a 1-h hold at 150 and $300^{\circ} \mathrm{C}$ (imitation of the conditions of artificial aging) on the microstructure of alloy $\mathrm{Al}-27 \% \mathrm{Cu}-$ $6 \% \mathrm{Si}$ obtained by variant 1 . The structural components were

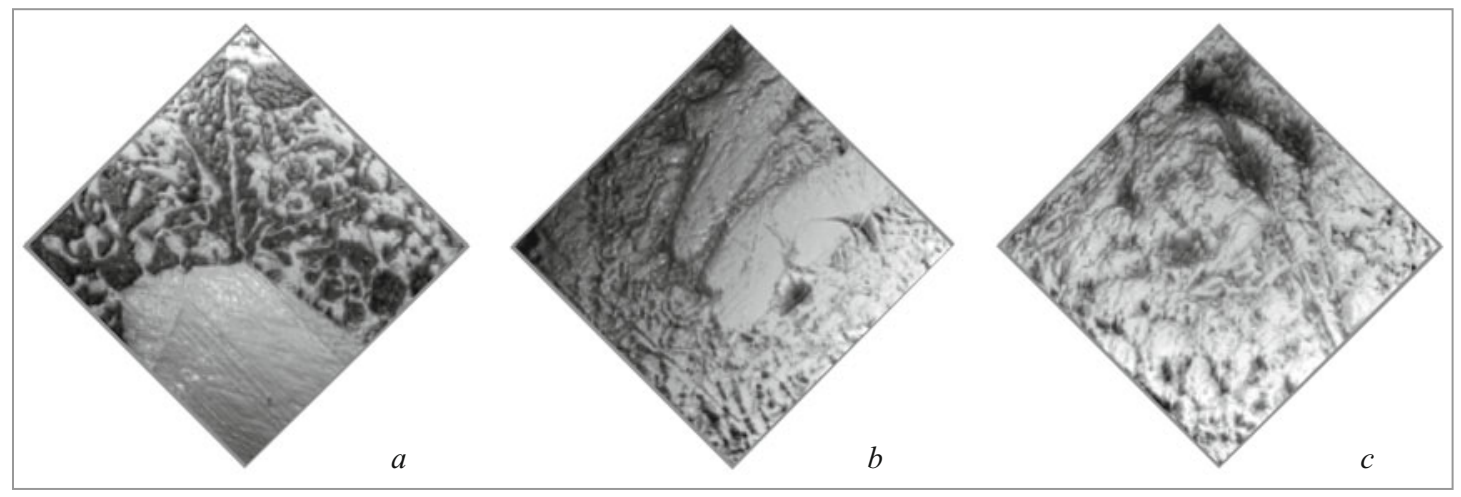

Fig. 4. Microstructure ( $3 d$-images) of alloy $\mathrm{Al}-27 \% \mathrm{Cu}-6 \% \mathrm{Si}$ obtained by variants $1(a), 2(b)$, and $3(c)$. Half-contact scanning probe microscopy $(\times 1200)$. 

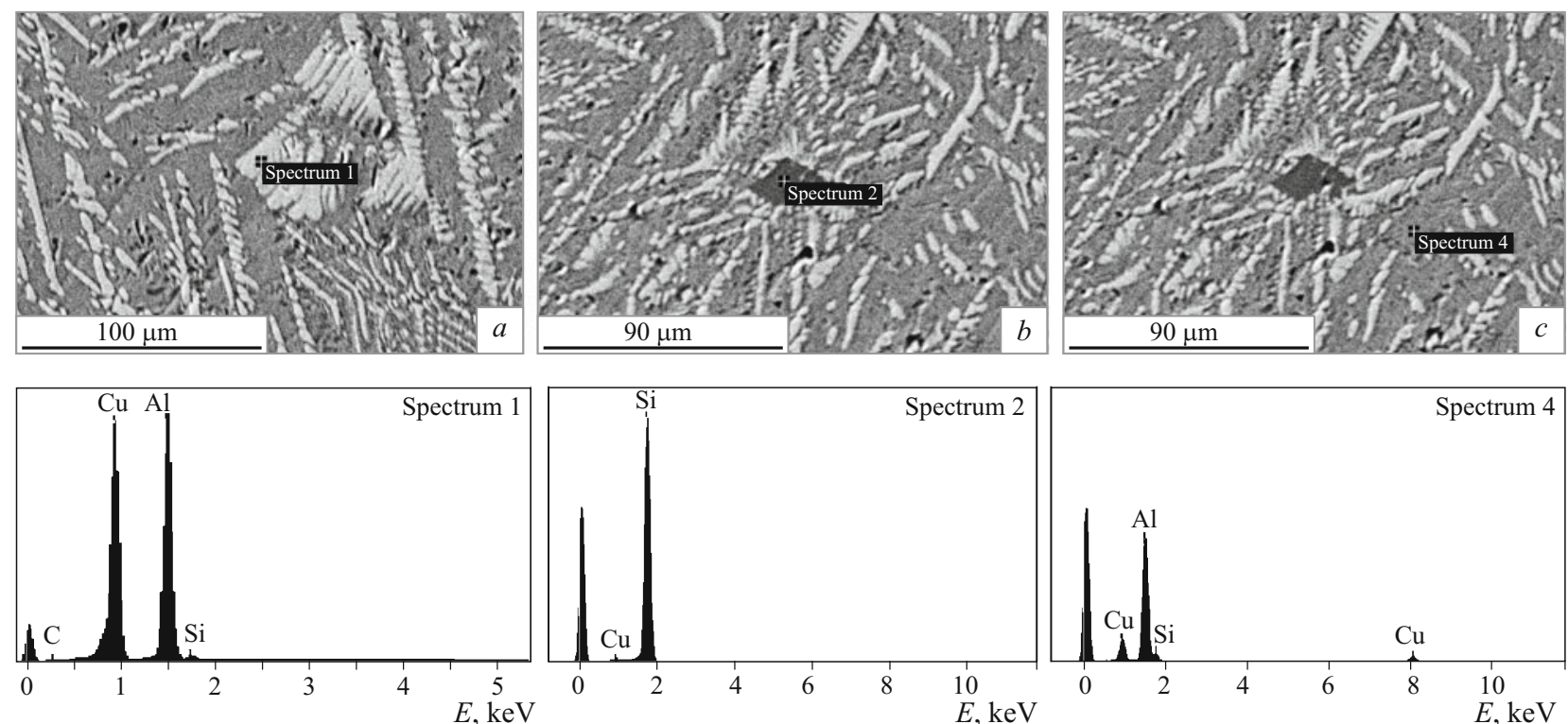

Fig. 5. Microstructure $(a-c)$ and results of a microscopic x-ray spectrum analysis $(d-f)$ of the solder obtained by variant 2 : $a, d)$ dendrites of $\alpha-\mathrm{Al} ; b, e)$ crystals of $\mathrm{Si} ; c, f)$ eutectic.

studied right in the mode of heating of the specimens on a special hot bench of a scanning probe microscope (SPM) (see Fig. 6). The SPM study of the surface of alloy Al $27 \% \mathrm{Cu}-6 \% \mathrm{Si}$ showed that the heating to $150^{\circ} \mathrm{C}$ had in- creased the volume fraction and the sizes of the $\mathrm{CuAl}_{2}$ crystals. The dendritic form of growth of the $\mathrm{CuAl}_{2}$ intermetallics was preserved upon growth in the thickness of both primary and secondary arms, and the crystals acquired well-

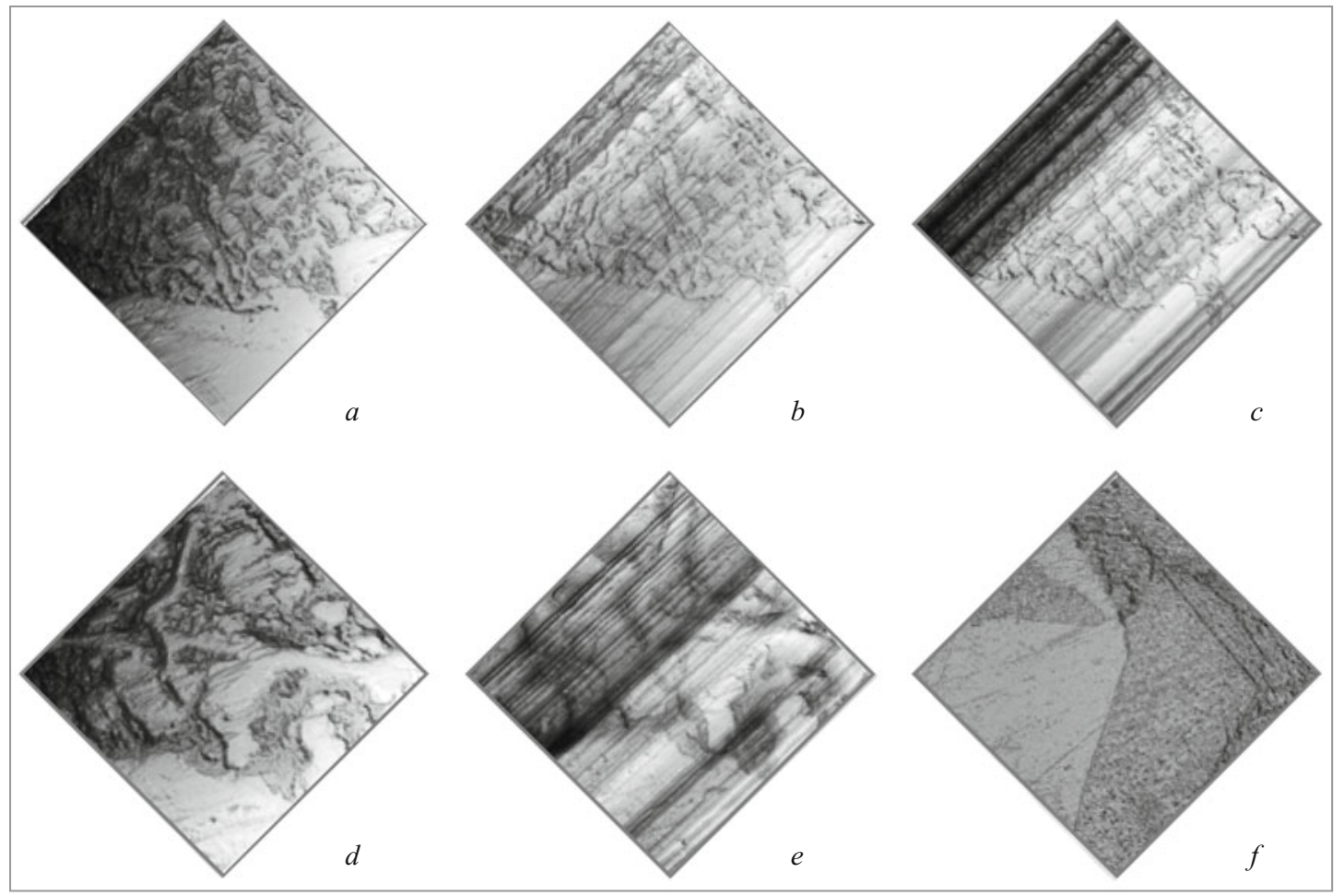

Fig. 6. Microstructure of alloy $\mathrm{Al}-27 \% \mathrm{Cu}-6 \% \mathrm{Si}$ obtained by variant 1 ( $3 d$-images, half-contact scanning probe microscopy). The heating temperature is: $\left.\left.\left.\left.a, d) 20^{\circ} \mathrm{C} ; b, e\right) 150^{\circ} \mathrm{C} ; c, f\right) 300^{\circ} \mathrm{C} ; a-c\right) \times 1200 ; d-e\right) \times 4800$. 
manifested faces. Increase in the temperature to $300^{\circ} \mathrm{C}$ changed the morphology (the features of recrystallization) of the crystals of primary silicon.

\section{CONCLUSIONS}

1. Superheating of alloy $\mathrm{Al}-27 \% \mathrm{Cu}-6 \% \mathrm{Si}$ to $1100^{\circ} \mathrm{C}$ lowers the specific heat of melting and crystallization by $10-17 \%$ and the activation energy by $25 \%$ and raises the liquidus and solidus temperatures by $3-5^{\circ} \mathrm{C}$ with respect to the characteristics of the alloy obtained without superheating in liquid state.

2. Superheating to $1100^{\circ} \mathrm{C}$ homogenizes alloy $\mathrm{Al}-$ $27 \% \mathrm{Cu}-6 \% \mathrm{Si}$; in subsequent cooling and crystallization at even a moderate rate (on the order of $1-10 \mathrm{~K} / \mathrm{sec}$ ) this leads to substantial changes in the structure and phase composition of the solid metal.

3. Special methods of treatment of melts cause refining and variation of the volume fraction of the main structural components of the alloy ( $\mathrm{Si}$ crystals, dendrites of $\alpha-\mathrm{Al}$, multiphase $\alpha+\mathrm{Si}+\mathrm{CuAl}_{2}$ eutectic). The crystals of primary aluminum are refined the most substantially (by $40 \%$ ) after the temperature and time treatment of the melt combined with fine-crystal remelting; the volume fraction of silicon increases by $25 \%$. The microhardness of the eutectic after such treatment increases by $17-25 \%$.

4. A hold of nonmodified alloy $\mathrm{Al}-27 \% \mathrm{Cu}-6 \% \mathrm{Si}$ at $150^{\circ} \mathrm{C}$ for $1 \mathrm{~h}$ causes growth in the volume fraction and in the sizes of $\mathrm{CuAl}_{2}$ crystals. When the temperature is raised to $300^{\circ} \mathrm{C}$, the morphology of the Si crystals changes (features of recrystallization).

The authors are grateful to I. G. Brodova (the Institute for Metals Physics of the Ural Branch of the Russian Academy of Sciences, Ekaterinburg) for the participation in the discussion of the results. The electron microscope studies and the scanning probe microscopy have been performed at the CUC "Modern Nanotechnologies" of the UrFU (Ekaterinburg).

\section{REFERENCES}

1. V. S. Zolotarevskii and N. A. Belov, Physical Metallurgy of Castable Aluminum Alloys [in Russian], MISiS, Moscow (2005), 376 p.

2. M. A. Epikhin, V. V. Zaboleev-Zotov, Yu. N. Mishchenko, et al., "Vertical sections of the aluminum-silicon phase diagram," in: Physical Metallurgy and Strength of Materials [in Russian], Volgograd (1968), pp. $368-372$.

3. I. E. Petrunina (ed.), A Handbook on Soldering [in Russian], Mashinostroenie, Moscow (2003), $480 \mathrm{p}$.

4. O. A. Korzhavina (Chikova), P. S. Popel', I. G. Brodova, et al., "Viscosity and electrical resistivity of $\mathrm{Al}-\mathrm{Si}$ melts and effect of their structural state on the structure of cast metal," Rasplavy, No. 1, 10 - 17 (1991).

5. I. G. Brodova, P. S. Popel, N. M. Barbin, et al., Initial Melts as a Base for Formation of Structure and Properties of Aluminum Alloys [in Russian], UrO RAN, Ekaterinburg (2005), 369 p.

6. K. V. Nikitin, I. Yu. Timoshkin, V. I. Nikitin, et al., "About the effect of special methods of treatment on the properties of melt and structure of A34 solder," Metallurg. Mashinostr., No. 4, 17 - 21 (2011).

7. S. V. Lepikhin, E. E. Baryshev, G. V. Tyagunov, et al., "Updating of VDTA-8M3 high-temperature differential thermal analyzer," Pribory, No. 6 (2004).

8. S. V. Lepikhin, E. E. Baryshev, G. V. Tyagunov, et al., "Updating of VDTA-8M3 high-temperature differential thermal analyzer," Zavod. Lab. Diagn. Mater., 71(4), 35 - 37 (2005).

9. Ya. Shestak, The Theory of Thermal Analysis: Physicochemical Properties of Inorganic Solids [Russian translation], Mir, Moscow (1987), $455 \mathrm{p}$.

10. W. W. Wendland, Thermal Methods of Analysis [Russian translation], Mir, Moscow (1978), 626 p.

11. G. O. Piloyan, An Introduction into the Theory of Thermal Analysis [in Russian], Nauka, Moscow (1964), 222 p. 